Journal of Engineering and Applied Sciences 14 (19): 7089-7092, 2019

ISSN: 1816-949X

(C) Medwell Journals, 2019

\title{
Acceleration of the Calcium Carbonate Precipitation in Hard Water by using Electrolysis Process
}

\author{
Mayson Anwar Abdullah \\ College of Petrolatum and Minerals, Tikrit University, Tikrit, Iraq
}

\begin{abstract}
Softening of limestone for very hard water treatment is usually applied as a conventional water treatment process for domestic use. However, for industrial use, this treatment does not apply because it requires an increment in time for the precipitation of magnesium and calcium. In this research, an investigation of the efficiency of electrolysis process applied firstly, process conducted with hard water only and secondly with an alkaline chemical dosing to remove non-carbonated hardness of hard water. Results indicates that the production of primary coagulant during electrolysis increase the precipitation of $\mathrm{CaCO}_{3}$ and $\mathrm{Mg}(\mathrm{OH})_{2}$. The overall rate of removal of this process is $70 \%$ which is less for 6 times than the time required for conventional wastewater treatment method.
\end{abstract}

Key words: Electrolysis process, hard water, formation of a $\mathrm{CaCO}_{3}$, electrolysis process, hardness of hard water, wastewater treatment

\section{INTRODUCTION}

Lime often applied for water contains high concentrations degree of dissolved solids such as magnesium, calcium as well as some types of iron water. In this process, at a $\mathrm{pH}$ of approx. The 11.00 and after the hydroxide ions addition, the magnesium ions will precipitate as solid magnesium hydroxide $\mathrm{Mg}(\mathrm{OH})$ (Bt Alwi et al., 2016; Sonne et al., 2012) the calcium reduction is achieved by adding sodium or sodium carbonate, $\mathrm{Na}_{2} \mathrm{CO}_{3}$ in the precipitated sludge until the calcium concentration reaches a predetermined value. In general, the calcium concentration is regulated for drinking water, a concentration of $60 \mathrm{mg} / \mathrm{L} \mathrm{CaCO}_{3}$ and magnesium with a maximum of $5 \mathrm{mg} / \mathrm{L}$ : the calcium concentration is regulated for $1 \mathrm{CaCO}_{3}$ and magnesium with a maximum of $5 \mathrm{mg} / \mathrm{L}$.

The process of soda lime was applied by Cavalcanti and Bonifacio in a mixture of "raw water": "carbonated water" in samples of the Water Treatment Plant, WTP in Brazil. The mixing channel where sampling is taken is preceded by the following procedures: sedimentation, filtration and disinfection. The results showed a final $\mathrm{pH}$ of approximately 11.00 which consider as insufficient for total distribution. This process has another disadvantage in which that it requires a long stop (over $8 \mathrm{~h}$ ) in the sedimentation tank to specify the total alkalinity and calcium carbonate, $\mathrm{CaCO}_{3}$ (Alwi et al., 2013). According to Agostinho the electrolysis process is used to remove impurities from various domestic wastewater, eutrophic water and industrial wastewater (Jordan and Mackay, 2015).

In water treatment, this process can be described as a combination of coagulation, flocculation, flocculation and disinfection, showing important effects on water purification such as colloidal destabilization (rapid staining), rapid flocculation with eroded electrode, electrochemical reactions of oxygen and hydrogen ions which improve the removal of certain industrial contaminants such as heavy metals, high oxidation, it also allows natural chlorine dissolved in raw water to convert into chloride ions, to improve chloride ions.

The process shows important effects on water purification such as colloidal destabilization (rapid coloration), rapid flocculation with eroded electrode, electrochemical reactions of oxygen and hydrogen ions which improve the removal of some industrial pollutants such as heavy metals and a strong oxidation.

As a water treatment process, electrolysis produces two forms of water: alkaline water and acidic water or oxidized. In the anode area, water is oxidized because the metal electrodes are arranged in ionic form and an electronic emission of metals occurs. $\mathrm{PH}$ is very low (below 3.0) and the water becomes acidic. There is also a low concentration of dissolved oxygen.

When the water of sodium chloride is under electrolysis, the oxidation process in the solution produce 


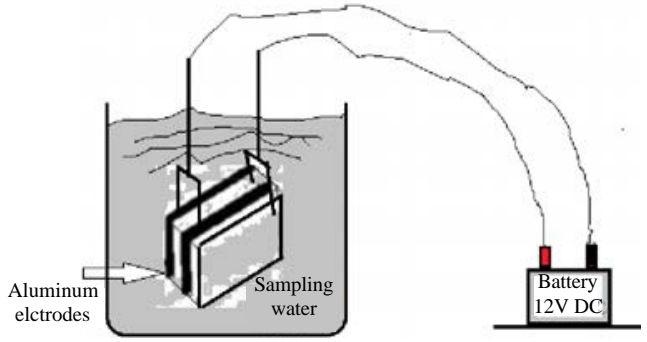

Fig. 1: Electrolytic cell block diagram

chloride rests, alkalinity is dissolved at the cathode and the water is reduced, so that, it becomes alkaline with $\mathrm{pH}$ values at an interval of about $1 \mathrm{~h}$, the water is reduced to hydrogen gas $\mathrm{H}_{2}$ and hydroxide ions, $\mathrm{OH}$-on the cathode surface and forms a localized surface of the cathode that is very little sensitive to mineral deposits.

The electrolytic cell consists of two-liter reactor, two steel electrodes and two aluminum electrodes. Everyone has an area of $50 \mathrm{~cm}^{2}, 2 \mathrm{~mm}$ thick and $0.5 \mathrm{~cm}$ separated from one to another. They were interconnected with different polarities on $12 \mathrm{~V}$ DC battery with flexible connecting wires. The anode is connected to the battery cathode and the cathode (electronic inox) is connected to the battery anode as shown in Fig. 1. Experiment was made on hard water in which the chemical doses of $316 \mathrm{mg} / \mathrm{L}$ of $\mathrm{NaOH}$ was applied. In water treatment, electrolysis can be defined as a combination of coagulation, flocculation, flotation and disinfection processes.

The effects observed are different: colloidal destabilization, rapid flocculation of electrodes with eroded materials and electrochemical reductions with the elimination of various industrial pollutants such as heavy metals, faster and stronger oxidation of others.

Electrolysis also allows the natural presence of chlorine in the form of chlorides dissolved in chlorides which produce raw water and other antibacterial substances that improve the disinfection process (Sheng, 2013, 2015). As a water treatment process, aqueous electrolysis produces two types of water (Han et al., 2013):

- Alkaline water is reduced

- Acid water oxidizes

In the anode, water is oxidized when the metal electrode is added to the solution where the $\mathrm{pH}$ of the metal decreases $(\mathrm{pH}<3.0)$ and the water in dissolved oxygen becomes acidic at the cathode the alkalinity decreases and by increasing the hydroxyl ion, water is produced as follows (Waters and Millero, 2013).

$$
2 \mathrm{H}_{2} \mathrm{O}+2 \mathrm{e}^{-} \rightarrow \mathrm{H}_{2(\mathrm{~g})}+2 \mathrm{OH}_{(\text {aq })}^{-}
$$

The hard water requires softening at a final calcium concentration of $60-70 \mathrm{mg} / \mathrm{L} \mathrm{CaCO}_{3}$ because the high concentration of chloride with values above $5000 \mathrm{mg} / \mathrm{L}$ and widespread use of metal components in water distribution networks (such as iron pipes) cause some corrosion in pipes. Lime process and kinetics of the magnesium precipitation that investigated by some researches such as Alwi et al. (2013). These studies have developed a design diagram called Modified Caldwell-Lawrence Diagram that permits calculating some chemical doses. After 5 years, Dost and Loewenthal, come to develop a very simple and fast, STASOFT which can be used for an advanced solid total solved soda drainage process up to about $15,000 \mathrm{mg} / \mathrm{L}$ (Zarga et al., 2013).

\section{MATERIALS AND METHODS}

The acceleration of the calcium carbonate precipitation in hard has been carried out in electrolysis process in two steps and compare the results of both steps. In the first step, the process was carried out with hard water sample without adding any alkaline chemical dosing, while in second step, the process was carried out by adding alkaline chemical dosing with hard water as follows:

Formation of $\mathrm{CaCO}_{3}$ during the electrolysis process: According to Marais and Loewenthal, the total Alkalinity (scale of $\mathrm{CaCO}_{3}$ ) is (Ghaffour et al., 2013):

$$
\Delta \mathrm{Alk}=-\mathrm{H}_{(\text {ad })}^{+}+\mathrm{HCO}_{3(\text { ad })}^{-}+\mathrm{CO}_{3(\text { ad })}^{2-}+\mathrm{OH}_{(\text {ad })}
$$

Where:

(ad) $\quad=$ Means the addition

$\Delta \quad=$ Indicates the change in concentration

$\mathrm{HCO}_{3}$ and $=$ Bicarbonate and carbonate

$\mathrm{CO}_{3}^{-2} \quad$ respectively

After the addition of lime, there is an instantaneous increase in $\mathrm{pH}$ and the change in alkalinity is equal to the settled amount. So:

$$
\Delta \mathrm{Alk}=\mathrm{OH}_{(\mathrm{ad})} ; \mathrm{Alk}_{\mathrm{ppt}}=\mathrm{OH}_{(\mathrm{ppt})}
$$

where, ppt belongs to the result of addition which equal concentration of calcium and hydroxide ions. So, the difference between calcium and alkalinity is:

$$
\mathrm{Ca}_{(\mathrm{ad})}^{2+}=\mathrm{BH}_{(\mathrm{ad})}^{+}
$$




$$
\begin{gathered}
\mathrm{Ca}_{3(\mathrm{ad})}^{2+}=\Delta \mathrm{Alk}=\Delta \mathrm{Ca} \\
\Delta \mathrm{C}_{2}=\Delta(\mathrm{Alk}-\mathrm{Ca})
\end{gathered}
$$

Water is then overcome with $\mathrm{CaCO}_{3}$ and precipitated over time.

Calculation of softening is carried out as follows: It is considered that each part of the sediment removes part of each magnesium and hydroxyl ions from the solution. The change in the acid is:

$$
\mathrm{Mg}_{\mathrm{ppt}}=\mathrm{OH}_{(\mathrm{ppt})}^{-}=\Delta \mathrm{AC}
$$

While, the increase in acidity and lime dosage is given by:

$$
\mathrm{CaO}_{\mathrm{ad}}=\Delta \mathrm{AC}=\left(\mathrm{Ac}_{\mathrm{i}}-\mathrm{Ac}_{\mathrm{f}}\right)+\mathrm{MgOH}_{2 \mathrm{ppt}}
$$

f.i "denotes the initial and the final value of the parameters. After excessive treatment with lime, the water forms a scale and should be neutralized to remove the alkaline core. The sodium or $\mathrm{Na}_{2} \mathrm{CO}_{3}$ content (sodium carbonate) is often added to minimize the calcium concentration and for water stability. Adding the soda causes the precipitation of the $\mathrm{CaCO}_{3}$, thus, the dose of $\mathrm{Na}_{2} \mathrm{CO}_{3}$ is determined as follows:

$$
\begin{gathered}
\mathrm{CaO}_{\mathrm{ad}}=\Delta \mathrm{Alk}-\mathrm{CO}_{3 \mathrm{ppt}}^{2-}=\Delta(\mathrm{Alk}-\mathrm{Ca})=\Delta \mathrm{C} 2 \\
\mathrm{Na}_{2} \mathrm{CO}_{3(\mathrm{ad})}=\Delta \mathrm{C} 2=\left(\mathrm{C}_{\mathrm{i}}-\mathrm{C} 2_{\mathrm{f}}\right)
\end{gathered}
$$

As far as acid is concerned, it stay unchanged. Stabilization is often required to reduce the $\mathrm{pH}$ to a prefix value by adding $\mathrm{CO}_{2}$. The Loewenthal index of $4 \mathrm{mg} / \mathrm{L} \mathrm{CaCO} \mathrm{CaC}_{3}$ is added to the end water, so, that when it comes to the grid, the water is saturated only with $\mathrm{CaCO}_{3}$.

\section{RESULTS AND DISCUSSION}

Table 1 shows the quality of drinking water before processing. Table 2 shows the quality of drinking water after adding the lime. Table 3 shows the quality of drinking water after the chemical processing with soda and lime. Figure 2 shows the total hardness minimization with time. The above values are obtained by using the

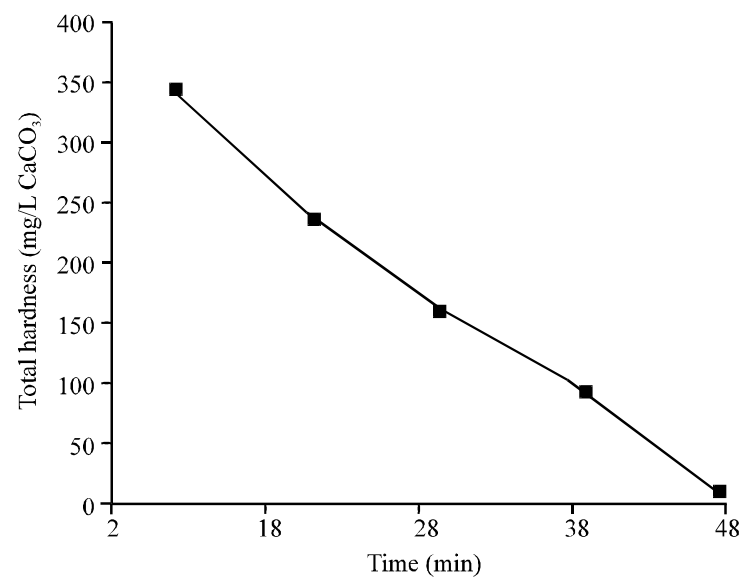

Fig. 2: Total hardness value $\left(\mathrm{mg} / \mathrm{L} \mathrm{CaCO}_{3}\right)$ after adding the lime to the hard water sample

Caldwell-Lawrence modulated diagram for an ionic strength of 0.010 and a temperature of $25^{\circ} \mathrm{C}$. In the anode electrolyte reactor, the following reaction was observed. Aluminum electrodes were eroded and freed from trivalent aluminum, $\mathrm{Al}_{3}^{+}$. This ion formed an ionic vapor of potassium sulfate rich in magnesium sulfate. There was the formation of aluminum sulphate which is a strong mpix. Good flocculation and coagulation were observed and the process also led to the removal of hardness of $70 \%$.

The addition of alkalizing chemicals allowed the $\mathrm{pH}$ to rise (although, discrete in comparison with the conventional process of aligning the lime). This caused the time-produced magnesium hydroxide to precipitate. It is important to say that the electrolysis process is able to offer a caustic to promote mechanisms for capturing, retaining and removing precipitation.

The following reactions and phenomena were observed on the cathode. The hydrogen ion was reduced to $\mathrm{H}_{2}$ gas which escaped to the surface of the liquid and retained the suspended solids. Magnesium is flocculated and absorbed by other materials suspended from water.

The phenomena governing the movement of $\mathrm{Ca}_{2}^{+}$ ions and $\mathrm{CO}_{3}{ }^{-}$ions on the electrode are mainly ionic transport and reactions of electrochemical load transfer. These reactions occur in the interface of the electrode/solution. In the electrolytic process there must be no precipitation of organic and inorganic salts, including the consumption of $\mathrm{Ca}_{2}^{+}$this occurs when chemical precipitation is preceded by electrocoagulation because chemical coagulation is the most widely used process for the treatment of drinking water throughout the world. 
J. Eng. Applied Sci., 14 (19): 7089-7092, 2019

Table 1: The quality of drinking water before processing

\begin{tabular}{|c|c|c|c|c|c|c|c|}
\hline Parameter & $\mathrm{pH}$ & $\begin{array}{l}\text { Alkalinity } \\
\left(\mathrm{mg} / \mathrm{L} \mathrm{CaCO}_{3}\right)\end{array}$ & $\begin{array}{c}\text { Acidity } \\
\left.(\mathrm{m} / \mathrm{L} / \mathrm{CaCO})_{3}\right)\end{array}$ & $\begin{array}{l}\text { Total hardness } \\
\left(\mathrm{mg} / \mathrm{L} / \mathrm{CaCO}_{3}\right)\end{array}$ & $\begin{array}{c}\text { Calcium } \\
\left.(\mathrm{mg} / \mathrm{L} \mathrm{CaCO})_{3}\right)\end{array}$ & $\begin{array}{l}\text { Magnesium } \\
(\mathrm{m} / \mathrm{L} / \mathrm{L} \mathrm{CaCO})_{3}\end{array}$ & Chloride $(\mathrm{mg} / \mathrm{L})$ \\
\hline Value & 7.5 & 110 & 112 & 325 & 232 & 110 & 246 \\
\hline Parameter & $\mathrm{pH}$ & $\begin{array}{l}\text { Alkalinity } \\
(\mathrm{mg} / \mathrm{L} \mathrm{CaCO})\end{array}$ & $\begin{array}{c}\text { Acidity } \\
\left.(\mathrm{mg} / \mathrm{L} \mathrm{CaCO})_{3}\right)\end{array}$ & $\begin{array}{l}\text { Total hardness } \\
\left(\mathrm{mg} / \mathrm{L} \mathrm{CaCO} \mathrm{CaCO}_{3}\right)\end{array}$ & $\begin{array}{c}\text { Calcium } \\
(\mathrm{mg} / \mathrm{L} \mathrm{CaCO})_{3}\end{array}$ & $\begin{array}{l}\text { Magnesium } \\
\left.(\mathrm{mg} / \mathrm{L} \mathrm{CaCO})_{3}\right)\end{array}$ & Chloride $(\mathrm{mg} / \mathrm{L})$ \\
\hline Value & 9.3 & 34 & 17 & 12 & 13 & 4 & 254 \\
\hline
\end{tabular}

Table 3: The quality of drinking water after the chemical processing with soda and lime

\begin{tabular}{|c|c|c|c|c|c|c|c|}
\hline Parameter & $\mathrm{pH}$ & $\begin{array}{l}\text { Alkalinity } \\
\left.(\mathrm{mg} / \mathrm{L} \mathrm{CaCO})_{3}\right)\end{array}$ & $\begin{array}{c}\text { Acidity } \\
\left.(\mathrm{mg} / \mathrm{L} \mathrm{CaCO})_{3}\right)\end{array}$ & $\begin{array}{l}\text { Total hardness } \\
\left(\mathrm{mg} / \mathrm{L} \mathrm{CaCO}_{3}\right)\end{array}$ & $\begin{array}{c}\text { Calcium } \\
\left(\mathrm{mg} / \mathrm{L} \mathrm{CaCO}_{3}\right)\end{array}$ & $\begin{array}{l}\text { Magnesium } \\
(\mathrm{mg} / \mathrm{L} \mathrm{CaCO})_{3}\end{array}$ & Chloride $(\mathrm{mg} / \mathrm{L})$ \\
\hline Value & 10 & 65 & -75 & 11 & 10 & 6 & 263 \\
\hline
\end{tabular}

Table 4: Total hardness values of hard water sample versus time

\begin{tabular}{lc} 
Time $(\min )$ & Total hardness $\left(\mathrm{mg} / \mathrm{L} \mathrm{CaCO}_{3}\right)$ \\
\hline 2 & 342 \\
9 & 243 \\
18 & 164 \\
28 & 105 \\
38 & 63 \\
48 & 23 \\
\hline
\end{tabular}

\section{CONCLUSION}

From the results obtained, we can conclude that the process of electrolysis accelerates the precipitation of calcium carbonate. It can then be said that the process focuses on the formation of a $\mathrm{CaCO}_{3}$ in the electrolysis process, so that, the hardness of hard water degree decreases. The high $\mathrm{pH}$ value gives refer to to the good participation of magnesium. An aluminum and sodium silicate $\left(\mathrm{NaALSi}_{3} \mathrm{O}_{8}(\mathrm{~s})\right.$ was formed that produce excellent flotation. Thus, results indicates that the electrolysis process for total hardness removal is not only cheap but it takes less time than a conventional water removal process. For industrial use this process allows the hardness to adapt to the required values.

\section{REFERENCES}

Alwi, N., I.K. Salleh, J. Irvine-Fortescue, G. Graham and S. Dyer et al., 2013. Scale and scale inhibition challenges for an alkaline surfactant polymer flood in a seawater flooded reservoir. Proceedings of the SPE International Symposium on Oilfield Chemistry, April 8-10, 2013, Society of Petroleum Engineers, The Woodlands, Texas, USA., ISBN:978-1 -61399-231-9, pp: 1-11.

Bt Alwi, N., I.K. Bt Salleh, J.M. Ibrahim, I. Carpenter and S.J. Dyer et al., 2016. Development of improved chemical formulations for scale control for alkaline surfactant polymer flood in a seawater flooded reservoir. Proceedings of the SPE International Conference on Oilfield Scale and Exhibition, May 11-12, 2016, Society of Petroleum Engineers, Aberdeen, Scotland, UK., ISBN:978-1-61399-455-9, pp: $1-2$.
Ghaffour, N., T.M. Missimer and G.L. Amy, 2013. Technical review and evaluation of the economics of water desalination: Current and future challenges for better water supply sustainability. Desalin., 309: 197-207.

Han, M., A. AlSofi, A. Fuseni, X. Zhou and S. Hassan, 2013. Development of chemical EOR formulations for a high temperature and high salinity carbonate reservoir. Proceedings of the IPTC 2013 International Conference on Petroleum Technology, March 26-28, 2013, European Association of Geoscientists and Engineers, Beijing, China, pp: 1-13.

Jordan, M. and E. Mackay, 2015. Predicting and managing inorganic scale associated with produced water from EOR projects. Proceedings of the SPE International Conference on Latin American and Caribbean Petroleum Engineering, November 18-20, 2015, Society of Petroleum Engineers, Quito, Ecuador, ISBN: 978-1-61399-422-1, pp: 1-18.

Sheng, J.J., 2013. Review of surfactant enhanced oil recovery in carbonate reservoirs. Adv. Petrol. Exp. Dev., 6: 1-10.

Sheng, J.J., 2015. Status of surfactant EOR technology. Petrol., 1: 97-105.

Sonne, J., K. Miner and S. Kerr, 2012. Potential for inhibitor squeeze application for silicate scale control in ASP flood. Proceedings of the SPE EOR International Conference on Oil and Gas West Asia, April 16-18, 2012, Society of Petroleum Engineers Muscat, Oman, ISBN: 978-1-61399-199-2, pp: 1-7.

Waters, J.F. and F.J. Millero, 2013. The free proton concentration scale for seawater $\mathrm{pH}$. Mar. Chem., 149: $8-22$.

Zarga, Y., H.B. Boubaker, N. Ghaffour and H. Elfil, 2013. Study of calcium carbonate and sulfate co-precipitation. Chem. Eng. Sci., 96: 33-41. 